\title{
Formative Assessment as A Factor in The Development of Student Personality
}

\author{
Elena N. Korneva ${ }^{1 *}$, and Tatyana L. Kuzmishina ${ }^{1}$ \\ ${ }^{1}$ Moscow Pedagogical State University, Department of Psychology of Education, Moscow, Russia
}

\begin{abstract}
The article is devoted to the development of the personality of a university student in the training process and the importance of finding an effective way to train future specialists. The formative assessment method is considered as an important factor in the development of self-esteem and motivational sphere of a young person. The study purpose was to reveal the current level of self-esteem and the value orientations specifics of first-year students of the faculty of pedagogy and psychology. In the course of an empirical study, a formative assessment method was used in the learning process of an experimental group of students (100 people). This method is associated with the immersion of future specialists in the process of evaluating educational material, developing their methods of testing knowledge, etc. The results of the study indicate the effectiveness of formative assessment for the development of personality and professional motivation of young people.
\end{abstract}

\section{Introduction}

In the modern world, the personality of a young person - a university student - is subject to increased requirements [1]. Society expects that a young specialist is ready for professional activity, has high self-esteem, and constantly strives for self-development and training. It must also adapt easily to changing working and living conditions. These postulates are described in many scientific papers [2].

One of the central indicators of professional maturity is an adequate self-assessment of the results of their activities. However, certain conditions must be created to form adequate self-assessment. The educational process at the university must be aimed at developing personal reflection and preparing students to solve problems of self-determination [3].

The task of searching for such tools that will increase students ' self-esteem, ability to perform tasks in a real situation, independently find information and get the necessary knowledge, solve problems becomes urgent. In a word, prepare a student to be successful in any activity. L. S. Podymova emphasises the importance of stimulating ways of self-learning of students, the ability to set goals, awareness of their capabilities, a reflection of learning ways $[4,5]$.

Thus, self-esteem plays the role of a non-permanent construct, it is modified, based on the knowledge of the individual about himself and his worldview. The problem of the

\footnotetext{
* Corresponding author: en.korneva@mpgu.su
} 
research is the need to develop the self-esteem of the student's personality within the educational process in higher school.

The purpose of this study was to study the influence of formative assessment on the development of students ' personality.

The theoretical and methodological basis of the research was the work of L.S. Podymova and V.A. Slastenin on the importance of developing a student's personality within the framework of professional education, as well as scientific works of foreign scientists [4].

One of the most effective ways to develop adequate and high self-esteem is the method of formative assessment, which has proven itself in many countries, including Russia.

Formative assessment is implemented throughout the entire course of study at the university and is a combination of various techniques and techniques. The main feature of formative assessment is the presence of constant feedback to students from the teacher.

This study reflects the relationship between the use of certain techniques of formative assessment with self-esteem and value orientations of pedagogical university students [6-15].

\section{Methods}

The study was conducted at the faculty of pedagogy and psychology of the Moscow State Pedagogical University (MSPU). It was attended by 200 first year students-future teacherspsychologists. The study used the O. I. Motkov's method "Self-Assessment of Personality" in the modification of B. A. Sosnovsky [16] and the Morphological Test of Vital Values by V. F. Sopov and L. V. Karpushina [5].

\section{Results}

At the first study stage, it was found that the future teacher-psychologists' self-esteem was at low and average levels (they had no confidence, did not feel in harmony with the outside world). At the same time, the subjects adequately assessed their abilities and capabilities as future professionals. Students' value orientations related to the areas of preserving their identity, active social contacts, and their prestige. The most important life areas were hobbies and social life.

Students participating in the study were divided into two groups. In the educational process, 100 students were introduced to formative assessment techniques, such as "Minute Review" (at the end of each class, students answer questions related to the learning process: what they understood and did not understand); "Test Questions Compiled by Students" (students develop their tests that are aimed at checking the students' understanding of the material); "Group Presentation Assessment Map" (this technique allows one to evaluate the result of joint activities in the preparation of the presentation: students fill out forms that mark the quality of work done in the classroom). The control group of students (100 people) continued to study using traditional pedagogical technologies. The work continued throughout the school year (two semesters).

\section{Conclusion}

Thus, the use of formative assessment technologies in working with future teachers and psychologists allowed us to develop important qualities and Outlook on life that contribute to the professional success of future specialists. The research results are currently being discussed in the professional community at conferences and meetings of the department of educational psychology of the MSPU. 


\section{References}

1. P.P. Brud, R. Rogoza, J. Cieciuch, Personality and Individual Differences 163, (2020)

2. A. Gegenfurtner, Heliyon 5, (2019)

3. E.N. Korneva, Problems of modern education 6, 64-68 (2017)

4. L.S. Podymova, The personal paradigm of innovative education. Pedagogical heritage of V.A. Slastenin: Horizons of the Future: monograph (Moscow State Pedagogical University, Moscow, 2015)

5. V.F. Sopov, L.V. Karpushina, Journal "Applied Psychology" 4, 9-30 (2001)

6. G. Kraaykamp, N. Notten, Research in Social Stratification and Mobility 45, 63-71 (2016)

7. M. Björklund, M. Jäntti, Labour Econ 19, $465-474$ (2012)

8. A. Feher, P.A. Vernon, Personality and Individual Differences (in press) (2020)

9. Ö. İspir, E. Elibol, B. Sönmez, Nurse Education Today 79, (2019)

10. Y. Li, L. He, K. Zhuang, X. Wu, J. Sun, D. Wei, J. Qiu, Neuropsychologia 136, (2020)

11. H.-Y. Liu, Nurse Education Today 88, (2020)

12. M.A. Oldham, Psychosomatics 61(3), (2020)

13. N. Shalala, J. Tan, M. Biberdzic, Personality and Individual Differences 162, (2020)

14. P.A. Tiffin, L.W. Paton, D. O'Mara, C. MacCann, J.W.B. Lang, F. Lievens, Medical Education 54(2), (2020)

15. M.A. Martin, Social Science Research 41(1), 33-47 (2012)

16. B.A. Sosnovsky, Laboratory workshop on general psychology (Education, Moscow, 1979) 